\title{
Design of Z-Source Inverter for Voltage Boost Application
}

\author{
Mahmooda Mubeen ${ }^{1}$ \\ Asst Prof, Electrical Engineering Dept, Muffakham Jah College of Engineering \& Technology, Hyderabad, India ${ }^{1}$
}

\begin{abstract}
The z-source inverter employs a unique impedance network (or circuit) to couple the inverter main circuit to the power source, thus providing unique features that cannot be obtained in the traditional voltage-source(or voltagefed) and current-source (or current-fed) inverters where a capacitor and inductor are used, respectively. Z-Source Inverter overcomes the limitations of traditional VSI \&CSI and provides a conversion, by controlling the shoot through duty cycle. In this paper the hardware design of three phase induction Motor of $0.25 \mathrm{HP}$ connected as load to Z-Source inverter, fed form rectifier as input is implemented. The hardware is divided into two parts: Main circuit, Control circuit. The main circuit consists of Isolation Transformer, Bridge rectifier \& Filter, Z-source network, Inverter bridge (using MOSFET'S as switches) \& Induction motor (3- $\Phi, 0.25 \mathrm{HP})$. The control circuit consists of Supply to microcontroller, Generation of isolated power supplies \& Isolation and gate driver circuit. All these circuits are simulated (MATLAB Simulink) and tested for individual performance and are integrated and connected to achieve the final circuit.
\end{abstract}

Keywords: Z-Source Inverter, MOSFET, Bridge Rectifier, Microcontroller, Isolation Transformer.

\section{INTRODUCTION}

Inverter is a power electronic circuit whose function is to convert dc input voltage to a symmetrical ac output voltage of desired magnitude and frequency. They are widely used in Industrial applications such as variable speed ac motor drives, induction heating, standby power supplies, and uninterruptible power supplies. Inverters can also be used for power factor improvement (FACTS). The input to the inverter may be from a battery, fuel cell, solar cell, or other dc source. The traditional inverters that are commonly used are VSI \& CSI. The V-source converter is a buck (step-down) inverter for dc-to-ac power conversion and the $\mathrm{V}$-source converter is a boost (step-up) rectifier (or boost converter) for ac-to-dc power conversion. On the other hand the I-source inverter is a boost inverter for dcto-ac power conversion and the I-source converter is a buck rectifier (or buck converter) for ac-to-dc power conversion. Both the converters are either a boost or a buck converter and cannot be a buck-boost converter and are vulnerable to EMI noise in terms of reliability. This is overcome by using a Z-Source Inverter which employs two inductors and two capacitors. By selecting the suitable values of Inductors and capacitors it can be used as VSI or CSI. Therefore without changing the circuit it can work as both Buck/Boost Inverter.

In this paper the voltage of the inverter can be controlled by controlling the on period of the switch and the frequency can be varied by varying the time period.

\section{METHODOLOGY}

The Impedance Source Network is a combination of two inductors and two capacitors. It is the energy storage or filtering element working as the second order filter for the Impedance Source inverter. It is more effective to suppress voltage and current ripples. The Inductor and capacitor requirement should be smaller compared to traditional inverters.

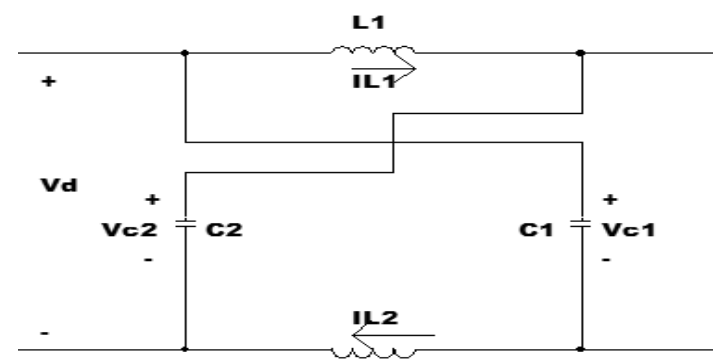

L2

The equivalent circuit of the Impedance source inverter is shown in Fig. below. The inverter bridge is equivalent to a short circuit when the inverter bridge is in the shootthrough zero state. The equivalent switching frequency from the Impedance source network is six times the switching frequency of the main inverter, which greatly reduces the required inductance of the Impedance source network.

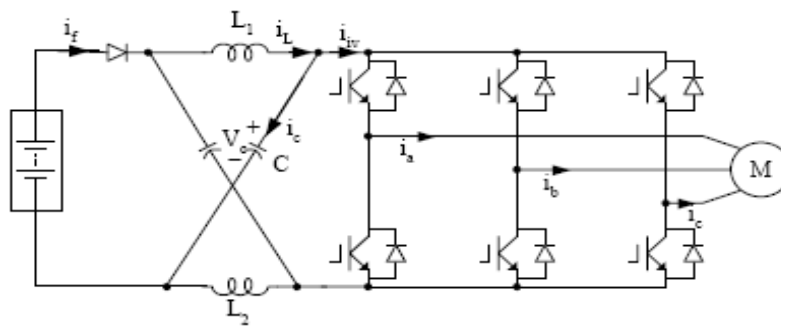

Fig: Impedance Source Inverter

The Impedance Source Inverter Bridge has one extra zero state. When the load terminals are shorted through both upper and lower devices of any one phase leg or all three phase legs. This shoot through zero state is forbidden in the VSI, because it would cause a shoot- through. This network makes the shoot through zero state possible. This state provides the unique boost feature to the inverter. 
INTERNATIONAL JOURNAL OF INNOVATIVE RESEARCH IN ELECTRICAL, ELECTRONICS, INSTRUMENTATION AND CONTROL ENGINEERING Vol. 4, Issue 2, February 2016

During the design of ZSI the most challenging is the estimation of values of the reactive components of the impedance network. The component values should be evaluated for the minimum input voltage of the converter, where the boost factor and the current stresses of the components become maximal. Calculation of the average current of an inductor

$$
\mathrm{I}_{\mathrm{L}}=\mathrm{P} / \mathrm{V} \text { in }
$$

The maximum current through the inductor occurs when the maximum shoot-through happens, which causes maximum ripple current. In our design, $60 \%$ peak-to-peak current ripple through the $\mathrm{Z}$-source inductor during maximum power operation is chosen. Therefore, the allowed ripple current is $\Delta \mathrm{I}_{\mathrm{L}}$, and the maximum current through the inductor is $\mathrm{I}_{\mathrm{L} \max }$

$$
\begin{gathered}
\mathrm{I}_{\mathrm{L} \max }=\mathrm{I}_{\mathrm{L}}+\mathrm{I}_{\mathrm{L}} * 30 \% \\
\mathrm{I}_{\mathrm{L} \min }=\mathrm{I}_{\mathrm{L}}-\mathrm{I}_{\mathrm{L}} * 30 \% \\
\Delta \mathrm{I}_{\mathrm{L}}=\mathrm{I}_{\mathrm{L} \text { max }}-\mathrm{I}_{\mathrm{L} \text { min }}
\end{gathered}
$$

The boost factor of the input voltage is:

$$
\mathrm{B}=1 /(1-2 \mathrm{Dz})=\mathrm{Vin} 1 / \mathrm{Vin}
$$

Where D0 is the shoot-through duty cycle:

$$
\mathrm{D} \mathrm{z}=(\mathrm{B}-1) / 2 \mathrm{~B}
$$

The capacitor voltage during that condition is

$$
\mathrm{V} \mathrm{c}=(\mathrm{Vin}+\mathrm{Vin} 1) / 2
$$

Calculation of required inductance of Z-source inductors:

$$
\mathrm{L}=\mathrm{T} \mathrm{z}^{*} \mathrm{Vc} / \Delta \mathrm{Ic}
$$

Where T0 - is the shoot-through period per switching cycle:

$$
\mathrm{Tz}=\mathrm{Dz} * \mathrm{~T}
$$

Calculation of required capacitance of Z-source capacitors:

$$
\mathrm{C}=\left(\mathrm{I}_{\mathrm{L}} * \mathrm{Tz}\right) /(\mathrm{Vc} * 3 \%)
$$

Hence the value of inductance and capacitance to be connected in $\mathrm{z}$-source network are calculated by using the above method the average current of an inductor for a load of $0.25 \mathrm{HP} 3$-phase Induction motor is

$$
\mathrm{I}_{\mathrm{L}}=\mathrm{P} / \mathrm{Vin}=186.5 / 250=0.746 \mathrm{~A}
$$

(Since $\mathrm{P}=0.25 * 746 \mathrm{~W}=186.5 \mathrm{~W}$ )

the maximum current through the inductor is $\mathrm{I}_{\mathrm{L} \max }$

$$
\begin{gathered}
\mathrm{I}_{\mathrm{L} \max }=\mathrm{I}_{\mathrm{L}}+\mathrm{I}_{\mathrm{L}} * 30 \%=0.746+0.223=0.969 \\
\mathrm{I}_{\mathrm{L} \min }=\mathrm{I}_{\mathrm{L}}-\mathrm{I}_{\mathrm{L}} * 30 \%=0.746-0.223=0.522 \\
\Delta \mathrm{I}_{\mathrm{L}}=\mathrm{I}_{\mathrm{L} \max }-\mathrm{I}_{\mathrm{L} \min }=0.4474 \mathrm{~A}
\end{gathered}
$$

The boost factor of the input voltage is:

$$
\mathbf{B}=1 /(1-2 \mathrm{Dz})=\mathrm{Vin} 1 / \mathrm{Vin}=300 / 250=\mathbf{1 . 2}
$$

Where D0 is the shoot-through duty cycle:

$$
\mathrm{Dz}=(\mathrm{B}-1) / 2 \mathrm{~B}=0.2 / 2.4
$$

The capacitor voltage during this condition is

$$
\mathbf{V c}=(\operatorname{Vin}+\mathrm{Vin} 1) / 2=\mathbf{2 7 5} \mathbf{V}
$$

Calculation of required inductance of Z-source inductors:

$$
\begin{gathered}
\mathrm{L}=\mathrm{Tz} * \mathrm{Vc} / \Delta \mathrm{Ic}=170.5 \mathrm{mH} \\
\mathrm{L}=170.5 \mathrm{mH}
\end{gathered}
$$

T0 - is the shoot-through period per switching cycle:

$$
\mathrm{Tz}=\mathrm{Dz} * \mathrm{~T}
$$

$\mathrm{Tz}=0.2775 \mathrm{~ms}$

Calculation of required capacitance of Z-source capacitors:

$$
\begin{gathered}
\mathrm{C}=\left(\mathrm{I}_{\mathrm{L}} * \mathrm{Tz}\right) /\left(\mathrm{Vc}^{*} * 3 \%\right) \\
\mathrm{C}=25 \mu \mathrm{F}
\end{gathered}
$$

\section{HARDWARE APPROACH}

\subsection{Block Diagram}

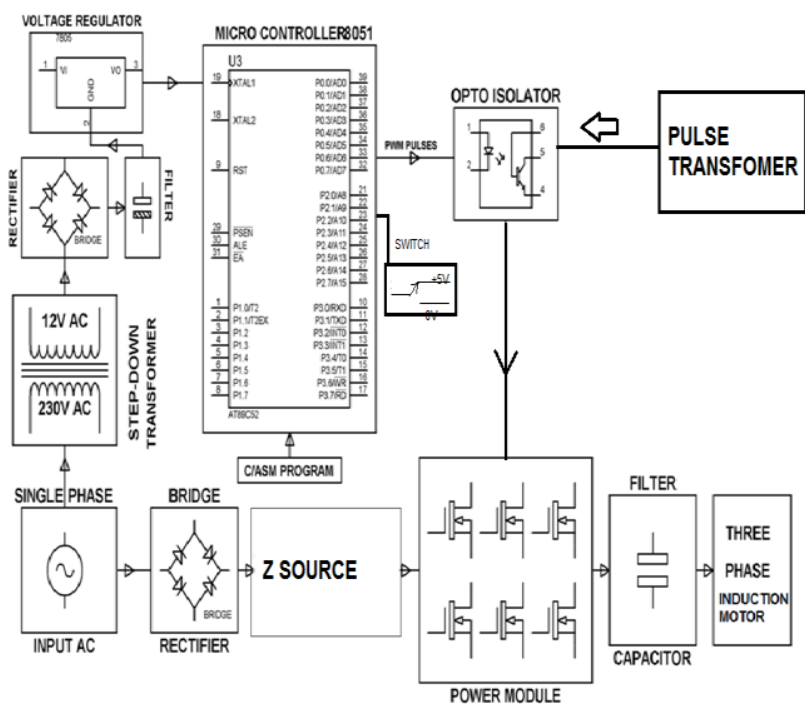

\subsection{Circuit Diagram}

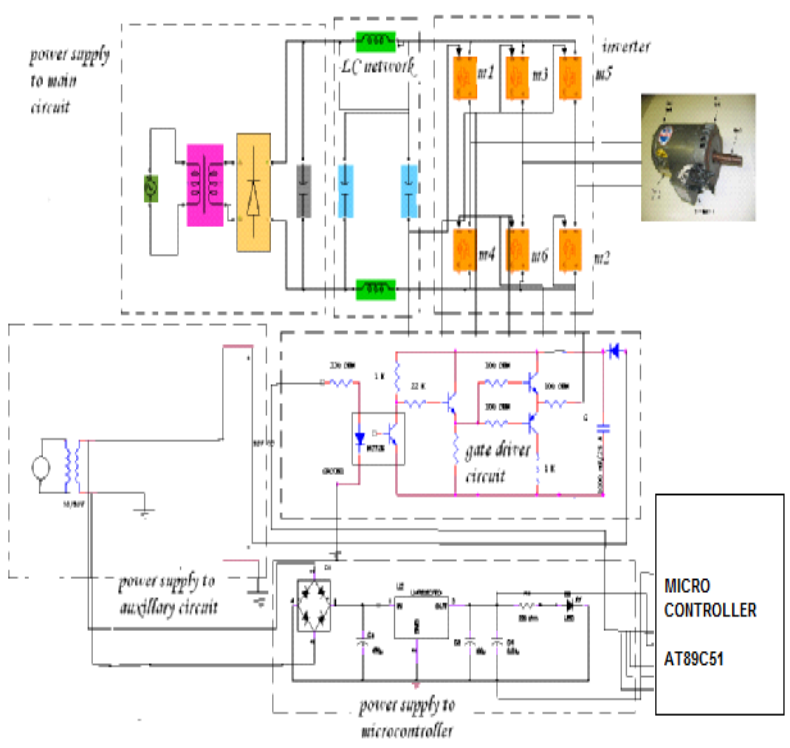

3.3 Hardware Model:

Hardware model is divided into two parts

- Main circuit

- Control circuit 
INTERNATIONAL JOURNAL OF INNOVATIVE RESEARCH IN ELECTRICAL, ELECTRONICS, INSTRUMENTATION AND CONTROL ENGINEERING Vol. 4, Issue 2, February 2016

\section{MAIN CIRCUIT: $(110 \mathrm{~V})$}

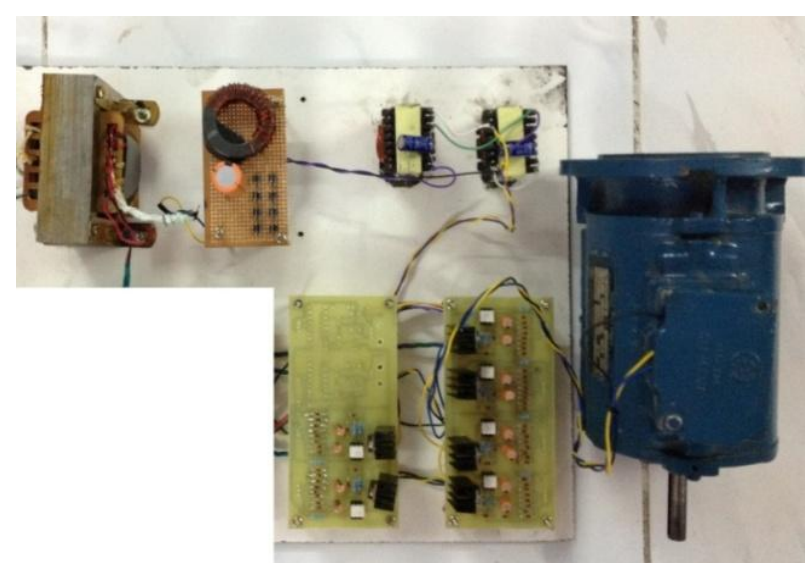

\subsection{1: MAIN CIRCUIT DIAGRAM}

It consists of the following components

- Isolation Transformer

In this paper we are using an isolation transformer of rating $100 \mathrm{VA}, 230 \mathrm{~V} / 230 \mathrm{~V}, 0.43 \mathrm{~A}$ to provide a necessary supply for the electronic circuits. Here we obtain two voltages of 12 volts and 110 volts for the control and main circuits respectively.

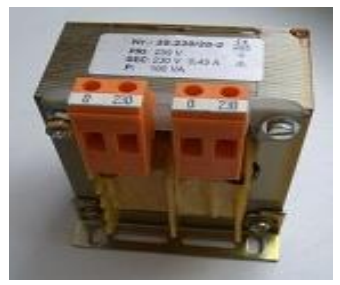

- Bridge rectifier \& Filter

The rectifier provides rectified DC output when supplied with AC input. The DC output of Rectifier has voltage of fixed polarity but pulsating magnitude. A smoothing Capacitor is connected to Rectifier Output. The function of this capacitor is to filter the ripples in the raw output voltage waveform, obtained from the bridge Rectifier. This capacitor value should be of very high value for low ripple. Thus, a capacitor of $1000 \mu \mathrm{f}$ with a working voltage of $25 \mathrm{v}$ is used.

\section{- Z-source network}

The Impedance Source Network is a combination of two inductors and two capacitors. The Impedance Source Network is the energy storage or filtering element for the Impedance Source inverter. This impedance source network provides a second order filter. This is more effective to suppress voltage and current ripples. The Inductor and capacitor requirement should be smaller compared to traditional inverters. Considering additional filtering and energy storage by the inductors, the Impedance Source Network should require less capacitance and smaller size compare with the traditional voltage source inverter, and considering additional filtering and energy storage by capacitors Z-Source network requires less inductance and smaller size compared with the traditional Current Source Inverters.

\section{- Inverter bridge}

The three phase 6-pulse bridge inverter is used to convert DC to AC whose pulses are supplied by AT89C51 Microcontroller which is programmed in C-language. The power inverter has 6 switches that are controlled in order to generate an $\mathrm{AC}$ output from the DC input. PWM signals generated from the AT89C51 micro controller controls these 6 switches. The phase voltage is determined by the duty cycle of the PWM signals that are applied to the DCto $-\mathrm{DC}$ converter. At a time, a maximum of three switches will be on, either one upper and two lower switches, or two upper and one lower switch. A dead time is given between switching off the upper switch and switching on the lower switch and vice versa. This ensures that both switches are not conductive when they change states from on to off, or vice versa. The motor is connected as load to inverter.

- Induction motor (0.25 HP)

A three phase 0.25 HP Squirrel Cage Induction Motor with Voltage $=230 \mathrm{~V}$, Power factor $=0.8$ lagging \& Speed $=1440 \mathrm{RPM}$ is being used as a load in the paper.

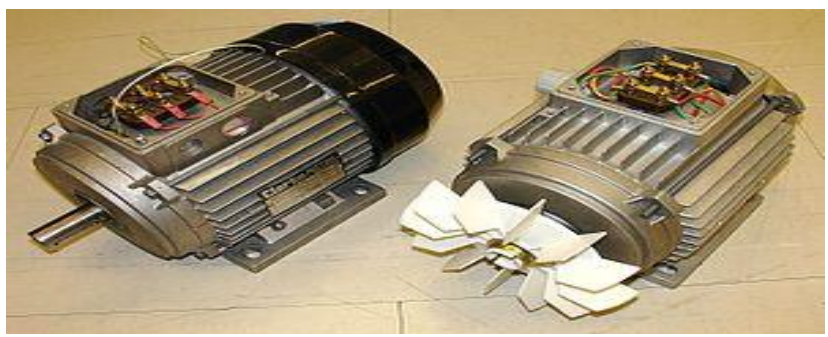

\section{CONTROL CIRCUIT: (12V)}

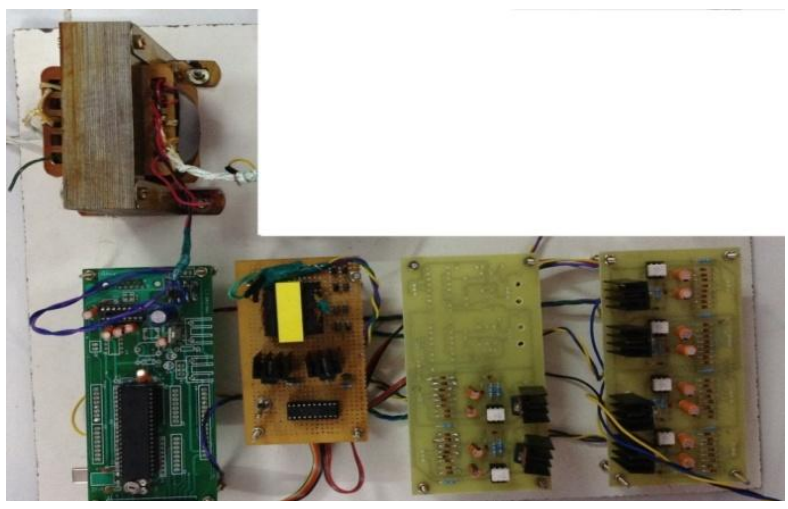

\subsection{2: CONTROL CIRCUIT DIAGRAM}

It consists of the following components:

- Supply to microcontroller

The microcontroller AT89C51 is used in the hardware design. It is used to generate PWM signals

- Generation of isolated power supplies

- Isolation and gate driver circuit

All these circuits are integrated and tested for individual performance and are inter connected to achieve the final circuit. 
INTERNATIONAL JOURNAL OF INNOVATIVE RESEARCH IN ELECTRICAL, ELECTRONICS, INSTRUMENTATION AND CONTROL ENGINEERING Vol. 4, Issue 2, February 2016

\section{FLOW CHART}

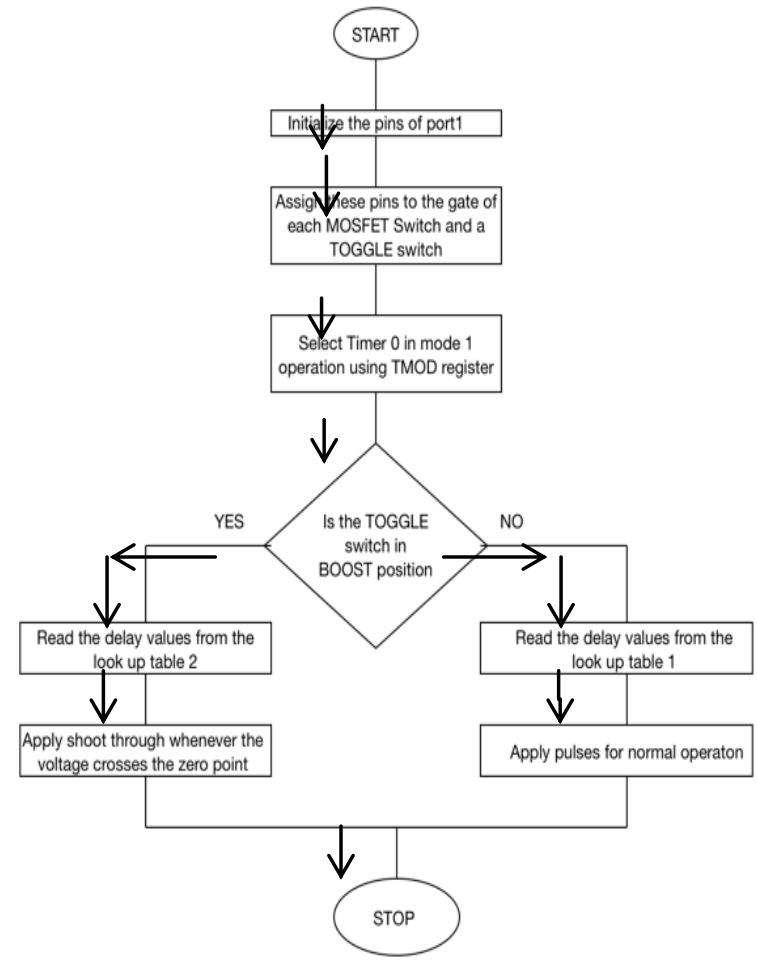

\section{SIMULATION RESULTS}

The various blocks of the block diagram are simulated seperately before they are put into actual hardware circuit.

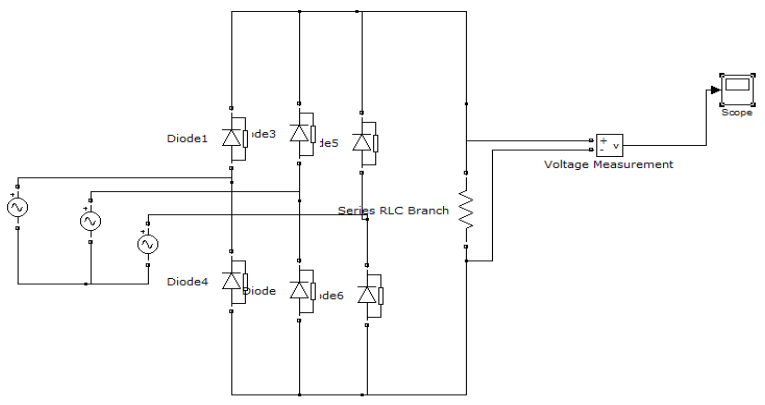

Fig: Three Phase bridge rectifier
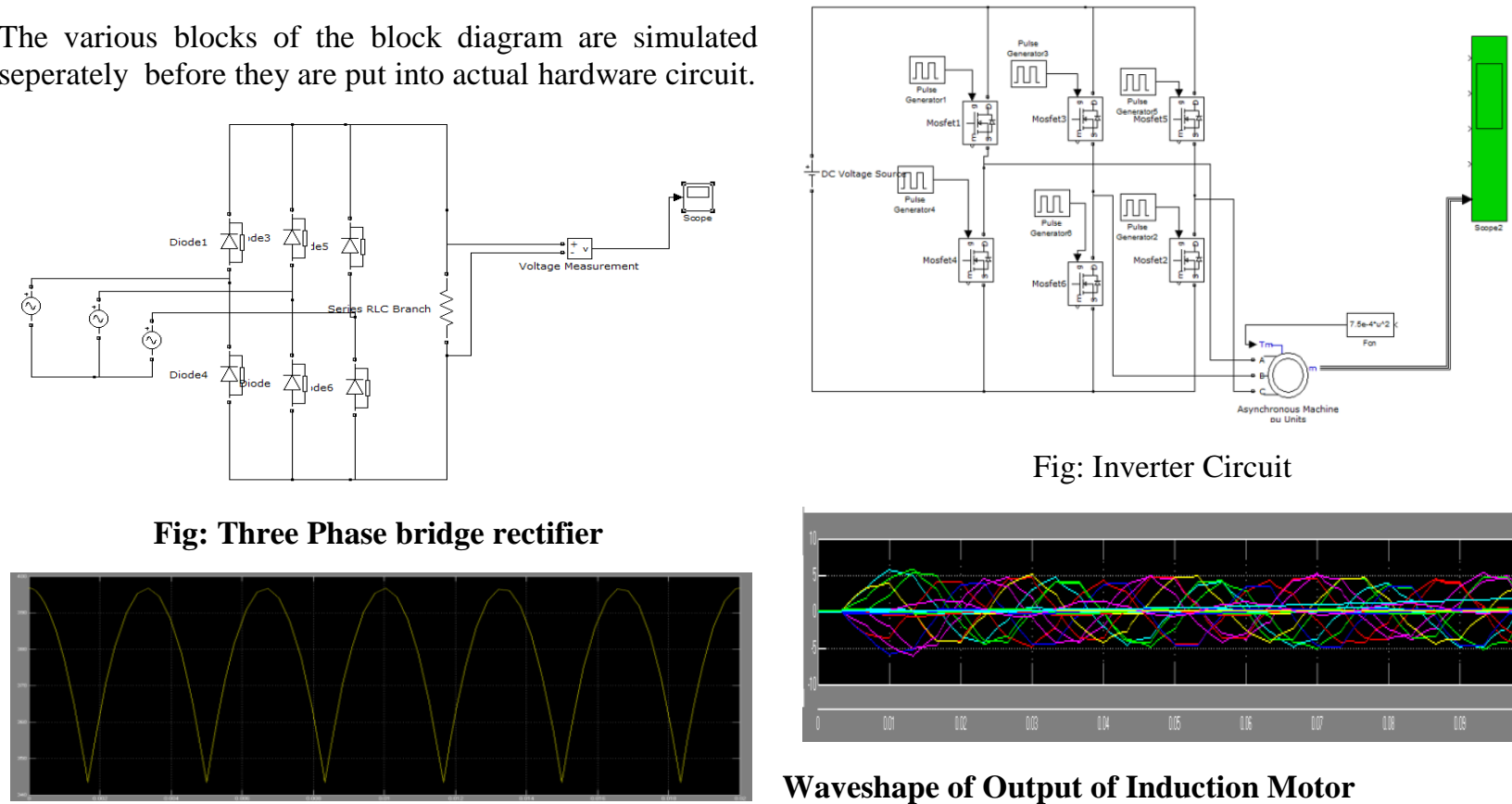

Fig: Inverter Circuit

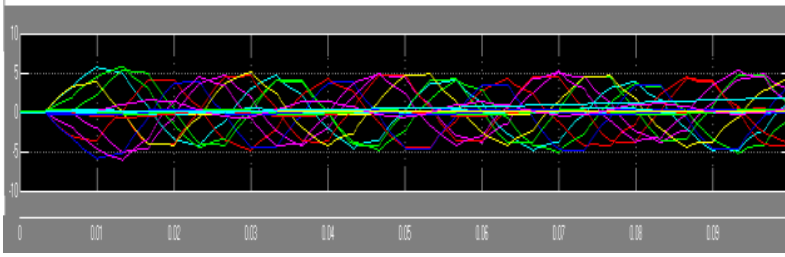

Waveshape of Output of Induction Motor

Fig: Rectified output voltage obtained from rectifier

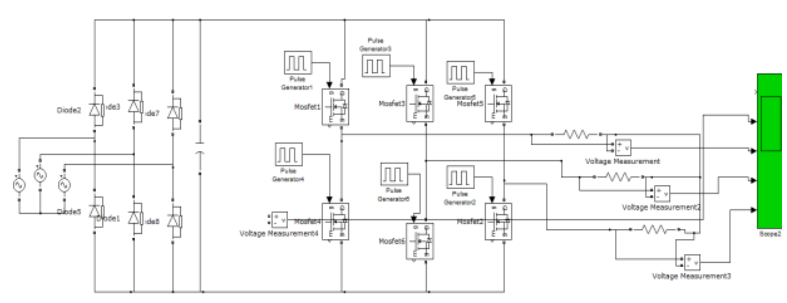

Fig: Inverter without Z-network (R-Load)

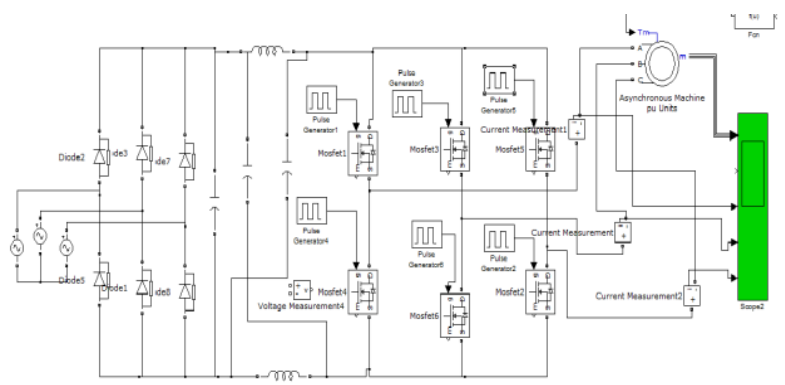

Fig: Inverter connected to $3 \Phi$-Induction Motor 


\section{CONCLUSION}

This paper presents the design and implementation of hardware of a basic Z-source inverter which demonstrates the boosting capability. In this circuit a three-phase induction motor of fractional hp is connected as a load and with the help of a toggle switch the boosting up of voltage is observed. Thus the designed circuits are working satisfactorily and are delivering the required performance. The speed of Induction Motor can also be adjusted by employing a speed set potentiometer setting. The frequency can be altered from $10 \mathrm{~Hz}$ to $50 \mathrm{~Hz}$ in a continuous manner along with the output voltage in order to maintain $\mathrm{V} / \mathrm{F}$ as constant. This primitive model can be extended for speed control of induction motor, when feedback is taken from the motor and given to control circuit such that output voltage from the inverter is varied along with the frequency keeping V/f constant and thereby obtaining variable speed.

\section{REFERENCES}

[1] FANG ZHENG PENG, senior member, IEEE, march/april-2003, "Z-source inverter", IEEE transaction on industrial applications, vol 39, no.2., pp. 504-510.

[2] FREDERICK D. KIEFERNDORF, Member, IEEE, MATTHIAS FORSTER and THOMAS A.LIPO, Fellow, IEEE, March/April2004. "Reduction of DC - Bus Capacitor Ripple Current with PAM/PWM Converter" IEEE Transactions on Industry Applications, Vol. 40.No.2, pp.607-615.

[3] YINGQI ZHANG, Student Member, IEEE, and PARESH C.SEN, Fellow, IEEE, November/December- 2003, “A New Soft-Switching Technique for Buck, Boost, and Buck- Boost Converters" IEEE Transactions on Industry Applications, Vol. 39.No.6, pp. 17751783.

[4] HELGA SILAGHI, .2000, “A Passive Series, Active Shunt Filter For High Power Applications" Notes, Department of Electrical drives and Automatisation, University of Oradea, pp. 83-88.

[5] ROBERT L. BOYLESTAD LOUIS NASHELSKY, -2000, "Electronics Devices and Circuit Theory", Prentice- Hall of India, New Delhi, pp. 238-247

[6] UMESH SINHA, -1994, "Network Analysis and Synthesis "Satya prakasan, Incorporating Tech India Publications, Fifth Edition, New Delhi, pp. 166-169, 583-587, 702-713.

[7] M.D. SINGH, K. B. KHANCHANDANI, -2003, "power electronics", tata McGraw hill limited, pp. 315-326, 349-367, 651667.

[8] ASHISH BENDRE, IAN WALLACE, JONATHAN NORD AND GIRI VENKATARAMANAN, JUNE 2001, "A Current Source PWM Inverter with Actively Commutated SCR's”, IEEE power electronics specialist conference, Vancouver, bc, Canada, pp.1-6. 